\title{
Heavy metals contamination in soils and selected edible parts of free-range local chicken
}

\author{
Z. J. Mbilu • M. E. Lyimo
}

Received: 26 June 2012/Revised: 28 October 2013/Accepted: 11 January 2014/Published online: 30 January 2014

(C) Islamic Azad University (IAU) 2014

\begin{abstract}
A study was carried out to determine the levels of heavy metals [(arsenic (As), mercury $(\mathrm{Hg})$, cadmium $(\mathrm{Cd})$ and lead $(\mathrm{Pb})$ ] contamination in soils and edible parts of free-range local chicken (liver, muscle tissues and abdominal fat) collected randomly in three locations viz Tabata, Kigogo and Vingunguti located in Dar es Salaam city, Tanzania. Concentration of $\mathrm{Pb}$ in soils ranged from 5.304 to 7.529, Cd from 0.046 to $0.055, \mathrm{Hg}$ from 0.034 to 0.060 and As from 0.239 to $0.329 \mathrm{ppm}$, respectively. Lead concentration in soils differed significantly $(P \leq 0.05)$ between locations. Differences in soil concentration of $\mathrm{As}, \mathrm{Hg}$ and $\mathrm{Cd}$ between locations were not significant $(P>0.05)$. Heavy metal concentration in chicken parts differed significantly between locations $(P \leq 0.05)$. High lead concentration in chicken parts was registered in samples collected at Tabata than at Kigogo and Vingunguti. As and $\mathrm{Cd}$ concentration in soil and that in liver and $\mathrm{Pb}$ concentration in soil and that in muscle tissues were positive and significant correlated $[(P \leq 0.001)$ and $(P \leq 0.05)]$, respectively. Negative significant $(P \leq 0.05)$ correlation was observed between $\mathrm{Hg}$ concentration in soils and that in liver and between As concentration in soils and $\mathrm{Hg}$ concentration in muscle tissues. Results have shown that heavy metals contaminated in soils may find route into different tissues and organs parts of free-range local chicken; a health concern,
\end{abstract}

\section{Z. J. Mbilu}

Department of Veterinary Pathology, Faculty of Veterinary

Medicine, Sokoine University of Agriculture, P.O. Box 3018,

Chuo Kikuu, Morogoro, Tanzania

\section{E. Lyimo ( $\bowtie)$}

Department of Food Science and Technology, Sokoine

University of Agriculture, P.O. Box 3006, Chuo Kikuu,

Morogoro, Tanzania

e-mail: monilyimo@yahoo.com hence, calls for safe disposal of industrial and domestic potential sources of heavy metal contamination in soils.

Keywords Liver - Abdominal fats $\cdot$ Muscle tissues $\cdot$ Soil contamination

\section{Introduction}

Food is usually the main source of human exposure to heavy metals. Heavy metals are considered to pose serious chemical health hazards to human and animals (Lars 2003). Heavy metals from man-made pollution sources are continuously released into aquatic and terrestrial ecosystems; and therefore, the concern about the effect of anthropogenic pollution on the ecosystems is growing. Contamination with heavy metals is a serious threat because of their toxicity, bioaccumulation and biomagnifications in the food chain (Demirezen and Uruc 2006). In Tanzania, and particularly in Dar es Salaam city, urban agriculture has been a normal practice along various river banks. These river/streams have been reported to be highly polluted by toxic chemicals from industries, which discharge wastewater untreated into receiving waters along the Msimbazi River valley (Mwegoha and Kihampa 2010). Unlike many other pollutants in the environment, heavy metals are non-biodegradable (Kaewsarn and Yu 2001). In nature, animals are subjected to multiple contamination sources due to their feeding behavior, as such they are considered as good integrators of environmental contaminations and good subjects for examination of pollution and its impacts on the population (Trust et al. 2000). Poultry in free range and small farm flock results in uncontrolled access to all sources of environmental pollutants since birds might accumulate elements not only from polluted soils, water, plants and geohelminths but also from various non-edible 
wastes and substances containing heavy metal compounds (Van Emous and Fiks-Van-Niekerk 2004). Meluzzi and Simincini (2005) reported that free-range poultry are exposed to heavy metal contamination due to their habits of fetching feeds almost everywhere even in highly contaminated domestic and industrial damping waste disposal areas.

Food chain contamination by heavy metals has become a burning issue in recent years because of their potential accumulation in biosystems through contaminated water, soil and air (Rajesh et al. 2004). Heavy metals accumulate in the organs (like kidney, liver, spleen, abdominal fats and muscles) of chicken due to consumption of feeds contaminated overtime, and once human beings consume these contaminated organs of chicken, the heavy metals will then accumulate in different organs of their bodies. The longer the exposure to heavy metals the higher the bioaccumulation in the body (Chan et al. 2003).

Collapsed sewer infrastructure and the disposal of industrial liquid wastes lead to wastewater, which may contain heavy metals and pathogenic microbes, find their way to the soils and free-range local chicken feeding areas. Consumption of local chicken has recently increased due to consumers awareness on the safety of edible parts of freerange local chicken compared to that of broilers, layers as well as red meat (Van-Overmeire et al. 2006). Many heavy metals can be very toxic and thus may threaten the health of animals (Tandon et al. 2003). Remediation of contaminated soils and water especially with heavy metals has received considerable attention in recent years, and technologies using plants and filtration have been developed and used to remove contaminants from polluted soils and water (Raskin et al. 1997; Garbisu and Alkorta 2001).

Several studies have been conducted to investigate heavy metal levels in environmental samples, as well as heavy metal accumulation and effects on organisms, and factors affecting their accumulation by various organisms. However, no studies have been carried out to correlate heavy metal concentration in soil and edible parts of free local chicken. Hence, this study aims at investigating whether there is relationship between the levels of heavy metals present in the soils and the amount found in local chicken feeding in these environments.

The research was carried out in January 2011 to December 2011 in selected locations of Dar es Salaam city followed by laboratory analyses carried out at the Seamic laboratory, Kunduchi, Dar es Salaam, Tanzania.

\section{Materials and methods}

Free-range local chicken of the age of 18 months were collected from three locations (Kigogo, Tabata,
Vingunguti) of Dar es Salaam city in Tanzania. The sex of these animals was not taken into consideration during sampling, and non-free-range local chicken was excluded in this study.

\section{Sample collection}

In each location, 15 sample plots (each plot representing a farmer) $0.5 \mathrm{~km}$ apart were demarcated. Farmers with flock sizes ranging between 10 and 30 free-range local chicken were randomly identified from each location. The age of the chicken in the study area ranged from 12 to 18 months. In each location, chicken of age 18 months were sampled. A total of 90 free-range local chickens were collected randomly from the identified farmers for all three wards (two replicate chicken per farmer $\times 15$ farmers $\times 3$ locations $=90$ chicken) viz. Tabata (30), Kigogo (30) and Vingunguti (30) chicken. Similarly, a total of 90 top surface soil samples were collected from areas where the freerange local chicken were collected (two replicate soil samples per farmer $\times 15$ farmers $\times 3$ location $=90$ soil samples). Top $10 \mathrm{~cm}$ soil samples of about $500 \mathrm{~g}$ each were packed in polythene bags and transported to the laboratory for analysis. All samples were collected in the same day to avoid variations.

\section{Sample preparation}

Chicken were slaughtered in batches and stored in cool box; samples of liver, abdominal fat and muscle tissue were collected from each of the 90 free-range local chickens, which were slaughtered, making a total of 270 samples. All samples were kept in dematerialized polyethylene sealable sample bags and kept in cool box and transported to Seamic laboratory, Kunduchi, Dar es Salaam, Tanzania for analysis.

\section{Drying and ashing of the edible parts}

Ten gram samples each of liver, muscles and abdominal fat of slaughtered free-range local chicken, were homogenized by using mortar and pestle, and then five grams of homogenized material were placed into $50-\mathrm{ml}$ quartz crucibles and dried in an oven set at $125 \pm 15{ }^{\circ} \mathrm{C}$ for $2 \mathrm{~h}$. Reference standard materials viz. a bovine liver (NBS SRH), a bovine muscle (BCR-278R) and a bovine fat (NBS FTN 276F), obtained from SIGMA Chemical Company, USA were included as quality control. The dried samples of abdominal fat were grounded using mortar and pestle to form paste and then returned back into crucibles. Liver and muscle tissues were ashed in a muffle furnace set at $550 \pm 20{ }^{\circ} \mathrm{C}$ for $24 \mathrm{~h}$ (instead of $12 \mathrm{~h}$ ), in order to enhance ashing process due to high 
moisture content of liver and muscle tissues. Ashed samples were removed from the oven and cooled to room temperature $\left(28 \pm 5^{\circ} \mathrm{C}\right)$.

\section{Digestion of edible parts}

The method described by Vos et al. (1991) and GonzalezWeller et al. (2006) was adopted in the extraction of metals from edible parts. The ashed samples of liver and muscle tissues were mixed with $3 \mathrm{ml}$ of $3 \mathrm{~N}$ nitric acid and dried on a hot plate at $120 \pm 15^{\circ} \mathrm{C}$ for half an hour, then placed in muffle furnace and temperature raised to $450{ }^{\circ} \mathrm{C}$ for $1 \mathrm{~h}$; this step was repeated three times to get constant weight, from which one gram samples were removed from muffle furnace, cooled to room temperature $\left(28 \pm 5^{\circ} \mathrm{C}\right.$ ) and dissolved in $1 \mathrm{ml}$ of $1 \mathrm{~N}$ hydrochloric acid. Two grams of abdominal fat were mixed with $1 \mathrm{ml}$ of $3 \mathrm{~N}$ nitric acid; and then, one gram of this mixture was dissolved in $1 \mathrm{ml}$ of $1 \mathrm{~N}$ hydrochloric acid. The obtained solutions of liver, muscle tissue and abdominal fat samples were transferred from the crucible to clean test tubes, $1 \mathrm{ml}$ of $0.2 \%$ nitric acid was added to the solutions, and the final solution was diluted with $8 \mathrm{ml}$ of double distilled water to make a total volume of $10 \mathrm{ml}$, which was then filtered by a $0.5-\mathrm{mm}$ Whatman filter paper to remove coarse particles; the final solutions of $10 \mathrm{ml}$ prepared in duplicate were used to analyze total $\mathrm{Cd}, \mathrm{Hg}, \mathrm{Pb}$ and $\mathrm{As}$. Quality control of analytical measurements was performed using blank samples and the reference materials [a bovine liver (NBS SRH), a bovine muscle (BCR-278R) and a bovine fat (NBS FTN 276F)]. Details of reference materials are as given above.

Preparation and digestion of soil samples

Arsenic, mercury, cadmium and lead contents in soil samples were determined according to AOAC (1995) method number 990.08. Standard reference materials for toxic metals in soils (BCR 146R No. 323), obtained from SIGMA Chemical Company, were used for quality control. Soil samples were dried in hot oven set at $105 \pm 15^{\circ} \mathrm{C}$ for overnight followed by grinding and sieving using a 2-ml sieve. Two grams of dried fine soil were digested with a mixture of $75 \%$ hydrochloric acid $(3 \mathrm{ml})$ and $25 \%$ nitric acid ( $1 \mathrm{ml}$ ) instead of $50 \%$ nitric acid because soils sample contained little organic materials (sand soil), fine and well dried. The mixture was heated at $95{ }^{\circ} \mathrm{C}$ on hot plate for $15 \mathrm{~min}$ and left overnight for digestion to take place; the resulted solution was diluted with $6 \mathrm{ml}$ of double distilled water and filtered by using $0.5-\mathrm{mm}$ Whatman paper. The clear solution obtained was used to analyze for $\mathrm{Cd}, \mathrm{Pb}, \mathrm{As}$ and total $\mathrm{Hg}$ in duplicate.
Instrument calibration and heavy metal determination

Concentrations of $\mathrm{As}, \mathrm{Cd}$ and $\mathrm{Pb}$ were determined by inductively coupled plasma optical emission spectrophotometer (ULTIMA JY 180 Modern ICP-OES) with detection limit of $0.001 \mu \mathrm{g} / \mathrm{g}$, and total mercury ( $\mathrm{T} \mathrm{Hg}$ ) was analyzed by using automated mercury analyzer (cold vapor technique). The calibration curves for the determination of other heavy metals were prepared using blank and working standard solutions. Lead, cadmium and arsenic were analyzed at their appropriate wavelengths (nm) of 220, 249 and 214 , respectively.

Statistical methods

Data were analyzed by using MSTAT-C statistical package, version 2.10 (1995). The experimental design used in this study was factorial design where location being factor A, chicken parts factor B and heavy metals factor C. Duncan's multiple range test was employed to examine which means differed significantly from the others using a significance level of 0.05 . Pearson's product-moment correlation coefficient $(r)$ was applied to measure the degree of linear relationship between the level of heavy metal contamination in soils and edible parts of the free-range local chicken at $5 \%$ level of significance.

\section{Results and discussion}

Lead concentration in the soils varied significantly between locations $(P \leq 0.05)$. Highest lead concentration was recorded in Tabata and lowest in Vingunguti. There was no significant difference $(P>0.05)$ in $\mathrm{As}, \mathrm{Cd}$ and $\mathrm{Hg}$ concentration levels between locations (Table 1). Variations in heavy metal concentration seem to be related to activities and levels of pollution of the areas.

Tabata is heavily populated industrial area. Contamination from these industries and from domestic wastes all

Table 1 Concentrations $(\mu \mathrm{g} / \mathrm{g}$ ) of heavy metals in soils (dry weight basis)

\begin{tabular}{lcccl}
\hline Location & Arsenic & Mercury & Cadmium & Lead \\
\hline Tabata & $0.239^{\mathrm{a}}$ & $0.060^{\mathrm{a}}$ & $0.055^{\mathrm{a}}$ & $7.529^{\mathrm{a}}$ \\
Kigogo & $0.305^{\mathrm{a}}$ & $0.034^{\mathrm{a}}$ & $0.046^{\mathrm{a}}$ & $5.887^{\mathrm{b}}$ \\
Vingunguti & $0.329^{\mathrm{a}}$ & $0.051^{\mathrm{a}}$ & $0.055^{\mathrm{a}}$ & $5.304^{\mathrm{c}}$ \\
Means & 0.291 & 0.048 & 0.052 & 6.241 \\
CV\% & 14.12 & 24.38 & 26.76 & 9.03 \\
SE \pm & 0.002 & 0.031 & 0.001 & 0.317 \\
\hline
\end{tabular}

$\overline{\text { a,b,c }}$ Means with same letters within the columns do not differ significantly at $P \leq 0.05$ according to Duncan's multiple range test (DMRT) 
Table 2 Concentrations ( $\mu \mathrm{g} / \mathrm{g}$ ) of heavy metals in liver of free-range local chicken (dry weight basis)

\begin{tabular}{lcccc}
\hline Location & Arsenic & Mercury & Cadmium & Lead \\
\hline Tabata & $0.086^{\mathrm{a}}$ & $0.034^{\mathrm{a}}$ & $0.016^{\mathrm{a}}$ & $5.624^{\mathrm{a}}$ \\
Kigogo & $0.089^{\mathrm{a}}$ & $0.021^{\mathrm{a}}$ & $0.029^{\mathrm{a}}$ & $4.008^{\mathrm{c}}$ \\
Vingunguti & $0.095^{\mathrm{a}}$ & $0.020^{\mathrm{a}}$ & $0.020^{\mathrm{a}}$ & $4.497^{\mathrm{b}}$ \\
Means & 0.090 & 0.025 & 0.022 & 4.718 \\
CV\% & 17.110 & 24.480 & 26.630 & 13.690 \\
SE \pm & 0.001 & 0.0001 & 0.0001 & 0.416 \\
\hline
\end{tabular}

a,b,c Means with same letters within the columns do not differ significantly at $P \leq 0.05$ according to Duncan's multiple range test (DMRT)

Table 3 Concentrations $(\mu \mathrm{g} / \mathrm{g})$ of heavy metals in muscle tissues of free-range local chicken (dry weight basis)

\begin{tabular}{lcccc}
\hline Locations & Arsenic & Mercury & Cadmium & Lead \\
\hline Tabata & $0.013^{\mathrm{a}}$ & $0.002^{\mathrm{a}}$ & $0.005^{\mathrm{a}}$ & $3.623^{\mathrm{a}}$ \\
Kigogo & $0.031^{\mathrm{a}}$ & $0.007^{\mathrm{a}}$ & $0.012^{\mathrm{a}}$ & $1.793^{\mathrm{b}}$ \\
Vingunguti & $0.059^{\mathrm{a}}$ & $0.005^{\mathrm{a}}$ & $0.005^{\mathrm{a}}$ & $2.458^{\mathrm{c}}$ \\
Means & 0.034 & 0.005 & 0.007 & 2.291 \\
CV\% & 21.650 & 25.900 & 19.020 & 23.540 \\
SE \pm & 0.001 & 0.0001 & 0.0001 & 0.440 \\
\hline
\end{tabular}

a,b,c Means with same letters within the columns do not differ significantly at $P \leq 0.05$ according to Duncan's multiple range test (DMRT)

these could have contributed to high levels of $\mathrm{Pb}$, leaking into the soils at Tabata compared to other locations. Presence of heavy metals in soils collected from industrial and wastes has also been reported by other workers (Nwajei et al. 2007). Car exhaust gases pollution, spilled oils and dust from worn out tires caused by heavy traffic in the study area could also be the source of $\mathrm{Pb}$ contamination in soils. However, the concentrations of $\mathrm{As}, \mathrm{Hg}$ and $\mathrm{Pb}$ detected in soils from the present study areas were lower compared to those reported by Mnali (2001) that were in the range of $0.44,0.10$ and $22 \mu \mathrm{g} / \mathrm{g}$ for $\mathrm{As}, \mathrm{Hg}$ and $\mathrm{Pb}$, respectively, for soils sampled at Lupa gold field in SouthWest Tanzania. The concentration of some heavy metals in the soils reflected the amounts that were determined in chicken organs. Results in Table 2 show that the free-range local chicken accumulated significantly $(P \leq 0.05)$ higher levels of $\mathrm{Pb}$ in liver than any other heavy metals (As, $\mathrm{Hg}$, and Cd) probably because of the higher levels of this metal observed in soils from these areas (Table 1). Concentration of $\mathrm{As}, \mathrm{Hg}$ and $\mathrm{Cd}$ in liver was lower and did not differed significantly $(P>0.05)$, suggesting low uptake and accumulation of these metals. Bokori et al. (1995) working on housed birds observed that the concentration of heavy metals was closely related to the levels of heavy metals in feedstuffs, the dose and the duration of heavy metal load.
Table 4 Concentrations $(\mu \mathrm{g} / \mathrm{g})$ of heavy metals in abdominal fat of free-range local chicken (dry weight basis)

\begin{tabular}{lrrrr}
\hline Locations & Arsenic & Mercury & Cadmium & \multicolumn{1}{c}{ Lead } \\
\hline Tabata & $0.084^{\mathrm{a}}$ & $0.029^{\mathrm{a}}$ & $0.014^{\mathrm{a}}$ & $5.859^{\mathrm{a}}$ \\
Kigogo & $0.062^{\mathrm{a}}$ & $0.026^{\mathrm{a}}$ & $0.023^{\mathrm{a}}$ & $3.514^{\mathrm{c}}$ \\
Vingunguti & $0.086^{\mathrm{a}}$ & $0.022^{\mathrm{a}}$ & $0.010^{\mathrm{a}}$ & $3.582^{\mathrm{b}}$ \\
Mean & 0.077 & 0.026 & 0.016 & 4.318 \\
CV\% & 24.490 & 16.240 & 25.820 & 12.640 \\
SE \pm & 0.001 & 0.001 & 0.001 & 0.298 \\
\hline
\end{tabular}

a,b,c Means with same letters within the columns do not differ significantly at $P \leq 0.05$ according to Duncan's multiple range test (DMRT)

Table 5 Summary of heavy metals correlations between soil and chicken edible parts (*values with significant correlation)

\begin{tabular}{lllll}
\hline Metal & As soil & $\mathrm{Hg}$ soil & $\mathrm{Cd}$ soil & $\mathrm{Pb}$ soil \\
\hline As (liver) & $0.811^{* * *}$ & $0.669^{*}$ & $\mathrm{~ns}$ & $\mathrm{~ns}$ \\
As (fat) & $\mathrm{ns}$ & $\mathrm{ns}$ & $\mathrm{ns}$ & $\mathrm{ns}$ \\
As muscle & $\mathrm{ns}$ & $\mathrm{ns}$ & $-0.809^{* * *}$ & $\mathrm{~ns}$ \\
$\mathrm{Hg}$ liver & $\mathrm{ns}$ & $-0.604^{*}$ & $\mathrm{~ns}$ & $0.652^{*}$ \\
$\mathrm{Hg}$ fat & $\mathrm{ns}$ & $\mathrm{ns}$ & $\mathrm{ns}$ & $\mathrm{ns}$ \\
$\mathrm{Hg}$ muscle & $-0.686^{*}$ & $0.686^{*}$ & $\mathrm{~ns}$ & $\mathrm{~ns}$ \\
$\mathrm{Cd}$ liver & $\mathrm{ns}$ & $\mathrm{ns}$ & $0.557^{*}$ & $\mathrm{~ns}$ \\
$\mathrm{Cd}$ fat & $0.662^{*}$ & $-0.655^{*}$ & $\mathrm{~ns}$ & $\mathrm{~ns}$ \\
$\mathrm{Cd}$ muscle & $\mathrm{ns}$ & $\mathrm{ns}$ & $\mathrm{ns}$ & $\mathrm{ns}$ \\
$\mathrm{Pb}$ liver & $\mathrm{ns}$ & $\mathrm{ns}$ & $\mathrm{ns}$ & $-0.903^{* * *}$ \\
$\mathrm{~Pb}$ fat & $\mathrm{ns}$ & $\mathrm{ns}$ & $\mathrm{ns}$ & $\mathrm{ns}$ \\
$\mathrm{Pb}$ muscle & $\mathrm{ns}$ & $\mathrm{ns}$ & $\mathrm{ns}$ & $0.601 *$ \\
\hline
\end{tabular}

$* P \leq 0.05$; ** $P \leq 0.01$; *** $P \leq 0.001$ significance level, $n s$ nonsignificant correlation, $n=9$

Higher levels of lead in liver could be attributed to its slow rate of elimination; hence, harmful levels could accumulate in tissues after prolonged exposure even to low quantities of lead (Barbosa et al. 2005). Similar trend of heavy metal accumulation was observed in muscle tissues and abdominal fat of free-range local chicken (Tables 3,4 ).

Presence of heavy metals in meat products collected from polluted areas has also been reported (Viqar-un-Nisa and Mohammad 2005 and Gonzalez-Weller et al. 2006) hence support results of this study. It has been observed that extensive contamination of various foods and beverages with heavy metals as well as their constant and continuous use represent a serious risk to human health, the most dangerous being $\mathrm{Pb}, \mathrm{Cd}$ and $\mathrm{Hg}$ as reported by Nordberg (2006). This author suggested that individuals, those living in areas polluted with such heavy metals and frequently consume local chicken are at higher risk of heavy metal contamination. However, the results of this study have revealed that the concentrations of $\mathrm{As}$ and $\mathrm{Cd}$ 
did not exceed the Tanzania Standards (TZS 2007) maximum limit in soils of $1 \mu \mathrm{g} / \mathrm{g}$ for both metals.

Heavy metals with significant correlations between soils and chicken edible parts are shown on Table 5. Concentrations of $\mathrm{As}, \mathrm{Cd}$ and $\mathrm{Pb}$ in soil showed significant and positive correlation with concentration of respective metals in the liver of free-range chicken, suggesting that high levels of these metals in the soil would likely lead to high uptake and accumulation in liver of chicken and vice versa. Contamination of soil with toxic metals thus can cause health hazards to chicken consumers.

Negative significant $(P \leq 0.05)$ correlation $(r=$ -0.604 ) was found between $\mathrm{Hg}$ concentration in liver and $\mathrm{Hg}$ concentration in soils suggesting that the origin of $\mathrm{Hg}$ contamination in liver of free-range local chicken could be from other sources other than soil. However, complicated kinetics of metals (absorption, distribution, metabolism, elimination, deposition and excretion) and their mutual interactions is almost impossible to predict metal effects or tissue concentrations based on their concentrations in environment (Lopez Alonso et al. 2004). In the case of free-range local chicken, the most probable heavy metals contamination source of liver, muscles tissue and abdominal fat is the environment (contaminated soil, grit, grass, earthworms and soil-dwelling insects) (Mubofu and Bahemuka1999).

Positive significant $(P \leq 0.05)$ correlation $(r=0.601)$ was found between $\mathrm{Pb}$ concentration in soil and muscle tissues of free-range local chicken suggesting that probably the origin of $\mathrm{Pb}$ in the muscle tissues could be due to contamination of this metal in soil. Negative significant $(P \leq 0.001) \quad$ correlations $(r=-0.809)$ were found between As concentration in muscle tissue and $\mathrm{Cd}$ concentration in soil. The interaction of these metals could likely not be direct as As, and $\mathrm{Cd}$ has different binding sites. Arsenic is bound to lipid, while $\mathrm{Cd}$ is bound to metal binding protein. Lopez Alonso et al. (2004) observed significant interactions between toxic ( $\mathrm{As}, \mathrm{Cd}, \mathrm{Hg}$ and $\mathrm{Pb}$ ) and nutritional essential elements ( $\mathrm{Ca}, \mathrm{Co}, \mathrm{Cr}, \mathrm{Cu}, \mathrm{Fe}, \mathrm{Mn}, \mathrm{Mo}$, $\mathrm{Ni}, \mathrm{Se}, \mathrm{Zn})$ in the tissues of cattle. Similarly, negative significant $(P \leq 0.05)$ correlation $(r=-0.686)$ was found between As concentration in the soil and $\mathrm{Hg}$ concentration in the muscle tissue. Chan et al. (2003) observed that the uptake of $\mathrm{Cd}, \mathrm{Cr}$ and $\mathrm{Zn}$ by macro alga Enteromarpha crinita and subsequent transfer to the marine herbivorous rabbit fish, sigunus canaliculatus.

Positive significant $(P \leq 0.05)$ correlation $(r=0.662)$ between As concentration in the soil and $\mathrm{Cd}$ concentration in abdominal fat was observed. Information on the mechanisms, uptake and accumulation of metals from soils to animal and bird body tissues is limited. Mariam et al. (2004) found that metal interactions can be due to modifications in absorption, metabolism, storage or excretion of one chemical by others, reactions at binding sites or receptors and due to physiological changes caused by other chemicals. Despite metal-metal interactions that occur in animal body, the rate of heavy metal bioaccumulation depends on amount of heavy metals taken and time of exposure.

\section{Conclusion}

Heavy metals in soil may find way into food chain. It is concluded that soil of the three selected sites of Dar es Salam city is contaminated with heavy metals. The most concerning conspicuous pollution is found from $\mathrm{Pb}$. The free-range local chicken of these areas tends to accumulate the metals from soil pose health hazard to consumers; community needs to find ways of de-contaminating the area and safe disposal of domestic and industrial wastes.

Acknowledgments The authors wish to acknowledge the Belgian Technical Cooperation (BTC) for providing funds to undertake the research and the Government Chemist Laboratory Agency technicians for their kind assistance in the chemical analysis.

\section{References}

AOAC (1995) Official methods of analysis, 15th edn. Association of Official Analytical Chemists Publication, Washington, DC

Barbosa F, Tanus-Santos J, Gerlach R, Parsons P et al (2005) A critical review of biomarkers used for monitoring human exposure to lead: advantages, limitations a future needs. J Environ Health Perspect 113(12):1669-1674

Bokori J, Fekete S, Glavits R, Kadar I, Koncz J (1995) Effects of prolonged dietary exposure of broiler chickens to cadmium. J Vet Hung 44:57-74

Chan SM, Wang W, Ni I (2003) The uptake of Cd, Cr and Zn by macro alga Enteromarpha crinita and subsequent transfer to the marine herbivorous rabbit fish, sigunus canaliculatus. J Environ Contam Toxicol 44:293-306

Demirezen O, Uruc K (2006) Comparative study of trace elements in certain fish meat and meat products. J Food Chem 32:215-222

Garbisu C, Alkorta I (2001) Phytoextraction A cost effective plantbased technology for the removal of metals from the environment. Bioresour Technol 77(3):229-236. doi:10.1016/S09608524(00)00108-5

Gonzalez-Weller D, Karisson LA, Caballero F, Hernadez A, Gutierrez T, Gonzelex I et al (2006) Lead and cadmium in meat and meat product consumed by the population in Tenerife Island, Spain. J Food Addit Contam 23:757-763

Kaewsarn P, Yu Q (2001) Cadmium removal from aqueous solution by pre treated biomass of marine padding spp. J Environ Poll 122:209-213

Lars J (2003) Hazards of heavy metal contamination. Br Med Bull 68:167-182

Lopez Alonso M, Prieto Montana F, Miranda M, Castillo C, Hernandez $\mathrm{J}$ et al (2004) Interactions between toxic (As, Cd, $\mathrm{Hg}$ and $\mathrm{Pb}$ ) and nutritional essential $(\mathrm{Ca} \mathrm{Co}, \mathrm{Cr}, \mathrm{Cu}, \mathrm{Fe}, \mathrm{Mn}, \mathrm{Mo}$, $\mathrm{Ni}, \mathrm{Se}, \mathrm{Zn}$ ) elements in the tissues of cattle from NW Spain. J Biomet 17:389-397 
Mariam I, Iqbal S, Nagra SA (2004) Distribution of some trace and macro minerals in beef, mutton and poultry. Int $\mathrm{J}$ Agric Biol $6: 816-820$

Meluzzi A, Simincini F (2005) Feeding hens diets supplemented with heavy metals. Arch Geflugelkd 3:119-225

Mnali SR (2001) Assessment of heavy metal pollution in the Lupa gold, SW Tanzania. Tanzan J Sci 27:15-22

Mubofu EB, Bahemuka TE (1999) Heavy metals in edible green vegetables grown along the sites of the Sinza and Msimbazi rivers in Dar es Salaam, Tanzania. Food Chem 66:63-66

Mwegoha WJC, Kihampa C (2010) Heavy metal contamination in agricultural soils and water in Dar es Salaam city, Tanzania. Afr J Environ Sci Technol 4(11):763-769

Nordberg GF (2006) Sub-cellular targets of cadmium nephrotoxicity. J Environ Health 114:191-194

Nwajei GE, Iwegbue M, Okafor MI (2007) Heavy metal in surfaces soils under waste dumps from Onitsha, Nigeria. J Biol Sci 7(2):405-408

Rajesh KS, Agrawal M, Mashall FM (2004) Effect of waste irrigation on heavy metal accumulation in soil and plants. Paper presented at National Seminar, Bangalore University, Bangalore Abstr. No. $7, \mathrm{p} 8$

Raskin I, Smith RD, Salt DE (1997) Phytoremediation of metals: using plants to remove pollutants from the environment. Curr
Opin Biotechnol 8(2):221-226. doi:10.1016/S0958-1669(97) 80106-1

Tandon SK, Singh S, Prasad S, Khandekar K, Dwivedi VK et al (2003) Reversal of cadmium induced oxidative stress by chelating agent, antioxidant or their combination in rat. J Toxicol Lett 145:211-217

Tanzania Bureau of Standards (TBS) (2007) Soil quality-limits for soil contaminants in habitat and agriculture. TZS 972:2007 (E)

Trust KAA, Brisbin IL, Hooper M (2000) Contaminant exposure and biomarker responses in spectacled eiders (Somateria fischeri) from St. Lawrence Island, Alaska. J Environ Contam Toxicol 38:107-113

Van Emous RA, Fiks-Van-Niekerk TG (2004) Higher mortality in free aviary houses. J World Poult 20(6):26-29

Van-Overmeire I, Pussemir L, Hanot D, Temmerman L, Hoeing M et al (2006) Chemical contamination of free-range eggs from Belgium food additives and contamination. J Food Addit Contam 23(11):1109-1122

Viqar-un-Nisa ANR, Mohammad M (2005) Levels of selected essential and toxic elements in the foodstuffs of Islamabad as analyzed by DPASV. J Toxicol Environ Chem 87(1):67-75

Vos PH, Lammers WV, Van C (1991) Arsenic, cadmium, and mercury in meat livers and kidneys of chicken slaughtered in the Netherlands. Z Lebensm Unters Forsch 187:1-7 